\title{
Effect of immunisation against leukaemia inhibitory factor on the establishment of pregnancy in sheep
}

\author{
D Vogiagis ${ }^{1 *}$, LA Salamonsen ${ }^{1}$, RM Sandeman ${ }^{3}$, TJ Squires ${ }^{2}$, \\ AR Butt ${ }^{1}$, RC Fry ${ }^{2}$ \\ 1 Prince Henry's Institute of Medical Research, Clayton, Victoria 3168; \\ 2 Victorian Institute of Animal Science, Werribee, Victoria 3030; \\ 3 La Trobe University, Bundoora, Victoria 3083, Australia
}

(Received 6 December 1996; accepted 23 June 1997)

\begin{abstract}
Summary - Leukaemia inhibitory factor (LIF), a pleiotropic cytokine, is implicated in blastocyst implantation in mice and maintains the development of ovine embryos in culture. Previously, LIF mRNA and protein were demonstrated in the endometrium throughout the oestrous cycle and early pregnancy in the ewe. In this study pregnant ewes were passively immunised against human recombinant LIF with polyclonal antibodies raised in cows by active immunisation. Ewes were immunised during two stages of early pregnancy: blastocyst development to hatching, and blastocyst elongation to implantation. Only animals passively immunised against LIF showed detectable LIF antibodies in their sera and in uterine lumina flushings by radioimmunoassay and Western blot analysis. Pregnancy was confirmed by ultrasound on day 55 and a $33.5 \%$ non-significant decrease in pregnancy rate of anti-LIF treated animals was observed, when compared to animals in control groups (untreated or treated with bovine anti-keyhole limpet hemocyanin). Cows actively immunised with recombinant human LIF and exhibiting high levels of LIF antibodies in their sera at the time of blastocyst implantation also showed a reduced pregnancy rate in comparison to control animals. Although LIF may not be obligatory for implantation in ruminants it does appear to have a role during the establishment of pregnancy.
\end{abstract}

\section{LIF / immunisation / early pregnancy / implantation}

Résumé - Effet de l'immunisation contre le LIF sur l'établissement de la gestation chez la brebis et la vache. Le rôle du LIF dans l'implantation chez la souris et dans le développement du blas-

\footnotetext{
* Correspondence and reprints: Department of Surgery, Monash University Medical School, Alfred Hospital, Prahran, Victoria 3181, Australia.

Tel: 6139276 2613; fax: 61395103365 ; e-mail: daphne@alfred.med.monash.edu.au
} 
tocyste ovin est bien établi. Les messagers codants pour le LIF et cette protéine sont présents dans l'endomètre de la brebis cyclique et en début de gestation. Ce travail rapporte les effets de l'immunisation passive contre le LIF chez des brebis gestantes. Du sérum de vaches immunisées activement contre le LIF a été injecté au moment de l'éclosion du blastocyste et entre l'élongation du blastocyste et l'implantation. Des anticorps anti LIF ont été détectés dans le sang (RIA) et dans des flushings utérins (Western Blot) des femelles immunisées. Par rapport aux contrôles, il a été observé une réduction du taux de gestation de $33.5 \%$ (échographie à j 55), non significative, chez les femelles immunisées. De même, les vaches immunisées activement contre le LIF ont présenté un taux de gestation réduit par rapport aux contrôles. Le LIF paraît donc jouer un rôle dans l'établissement de la gestation même s'il n'est pas obligatoire.

\section{LIF / immunisation / début de gestation / implantation}

\section{INTRODUCTION}

Leukaemia inhibitory factor (LIF) is a pleiotropic cytokine that acts on many different cells (Hilton 1992; Metcalf 1992). When mouse blastocysts were cultured in the presence of LIF they had a greater mass of trophectoderm in comparison to control blastocysts (Robertson et al, 1991) and LIF significantly increased the number of embryos hatching and exhibiting trophoblast outgrowth (Lavranos et al, 1995). Furthermore, recombinant human LIF improved the development of ovine embryos in culture (Fry et al, 1992) indicating that LIF may be one of many factors involved in improving embryo viability during sustained in vitro culture.

In the mouse uterus, LIF is expressed in the endometrial glands coincident with the time of blastocyst implantation (Bhatt et al, 1991) and mice that lack a functional LIF gene have normal blastocysts that fail to implant (Stewart et al, 1992). Furthermore, the low affinity LIF receptor (LIFR) is an integral component of the functional LIF receptor complex and interacts with gp 130 to form a high affinity receptor (Ip et al, 1992; Taga and Kishimoto, 1992; Gearing et al, 1992; Davis et al, 1993). Disruption of LIFR leads to perinatal death as mice homozygous for the mutation die shortly after or during birth (Ware et al, 1995), while embryos homozygous for the gp130 mutation die between 12.5 days postcoitum and term (Yoshida et al, 1996). In both cases normal implantation of embryos occurs, suggesting that endometrial LIF may not act directly through LIFR or gp130 on the blastocyst. Since both mutations are lethal their effects in adult mice cannot be investigated.

In human endometrium, LIF mRNA is present transiently with the highest expression observed during the mid and late secretory phases of the menstrual cycle (Charnock-Jones et al, 1994; Kojima et al, 1994; Arici et al, 1995; Vogiagis et al, 1996a; Cullinan et al, 1996). Immunoreactive LIF has been localised in the endometrial epithelium and stroma throughout the menstrual cycle (Vogiagis et al, 1996a), indicating that LIF may have a role in endometrial function. We have demonstrated previously that LIF mRNA and protein are present in the ovine uterus during early pregnancy (Vogiagis et al, 1996b), although these are not confined to the time of blastocyst implantation as in the mouse (Bhatt et al, 1991).

The sheep, unlike the human and mouse, has a characteristically long intrauterine blastocyst development before implantation (Bindon, 1971). Whereas in the mouse the blastocyst hatches from the zona pellucida and implants on the uterine wall on the 
fourth day of pregnancy (Finn and McLaren, 1967; Orsini and McLaren, 1967), in the sheep hatching and implantation occur about eight days apart (Bindon, 1971; Rowson and Moor, 1976). Thus the effects of LIF on preimplantation growth, development and subsequent implantation of the ovine blastocyst can be investigated.

In this study, we passively immunised pregnant ewes against LIF in an attempt to temporarily reduce or block the amount of LIF available to target cell receptors of the uterus and/or embryo. Two important stages of early pregnancy were examined: 1) blastocyst development to hatching; 2) blastocyst elongation to implantation. The large quantities of polyclonal antibodies against LIF utilised in the passive immunisation study, were obtained by actively immunising pregnant cows against LIF and collecting colostral immunoglobulin $\mathrm{G}(\mathrm{IgG})$. As a secondary objective, the effect of active immunisation against LIF on embryo implantation in these cows was assessed by re-immunising and re-mating the animals to boost their antibody levels during the early stages of a second pregnancy.

\section{MATERIALS AND METHODS}

All animal experimentation was approved by the animal ethics committee at the Victorian Institute of Animal Science, Werribee.

\section{Active immunisation of cows with LIF}

Pregnant Friesian cows were actively immunised with either human recombinant glycosylated LIF from Chinese hamster ovary [CHO] cells (AMRAD Pharmacia Biotech; $n=3$ ), or keyhole limpet hemocyanin (KLH, control; $n=2$ ), which was emulsified in Freund's complete or incomplete adjuvant. Animals received a $50 \mu \mathrm{g}$ dose at 10 (sub-cutaneously, behind the ear), 6 and 2 (intramuscular, hind leg) weeks prior to calving. Blood samples were collected from the tail vein prior to each immunisation and were assayed for anti-LIF. Colostrum was harvested after calving.

\section{Purification and preparation of bovine colostral IgG for immunisation}

Bovine colostral IgG was isolated by ammonium sulphate precipitation (Fang and Mukkur, 1976) then reconstituted $(67 \mathrm{mg} / \mathrm{mL}$, saline, $0.01 \%$ sodium azide) and centrifuged. The supernatant was filtered (Suporcap-50, $0.45 \mu \mathrm{m}$ ), dialysed (phosphate buffered saline [PBS] 3 days, $4^{\circ} \mathrm{C}$ ) and filtered (Acrocap $0.2 \mu \mathrm{m}$; Gelman Sciences, MI, USA). Injection material administered to sheep at days 12-16 was purified further to remove possible endotoxin using Affi-Prep polymixin beads (Bio-Rad, CA, USA).

\section{Western blot analysis}

Human recombinant non-glycosylated LIF (50 ng, AMRAD) was subjected to polyacrylamide gel electrophoresis on a $12 \%$ gel and the protein transferred to nitrocellulose. Non-specific binding was blocked with $5 \%$ ovalbumin (Sigma) and the filter probed with bovine serum (collected before third immunisation of LIF or $\mathrm{KLH} ; 1: 5000$ ). Bound antibodies were detected with horseradish peroxidase-conjugated goat anti-bovine IgG using a chemiluminesence kit (Amersham International).

\section{LIF radio-immunoassay}

Radio-iodinated recombinant human non-glycosylated LIF ( ${ }^{125}$ I-LIF) was provided by Dr DJ Hilton (Walter and Elisa Hall Institute, Melbourne, Australia). LIF immunoassay was established to test antibody binding to ${ }^{125}$ I-LIF. Samples were diluted in PBS (with $0.1 \%$ [v/v] Triton $\mathrm{X}-100,0.1 \%[\mathrm{w} / \mathrm{v}] \mathrm{BSA}, 0.02 \%[\mathrm{w} / \mathrm{v}]$ sodium azide; Sigma), assayed in duplicate with ${ }^{125}$ I-labelled LIF 10000 counts per minute $\left(4\right.$ days; $4{ }^{\circ} \mathrm{C}$ ). Separation of bound from free ${ }^{125}$ I-LIF was achieved by donkey anti-sheep serum $(1: 160,1 \mathrm{~h})$ before addition of 3.3\% PEG and $0.05 \% \mathrm{NaCl}\left(1 \mathrm{~h} ; 4^{\circ} \mathrm{C}\right)$. Tubes were centrifuged $\left(4000 \mathrm{rpm}, 30 \mathrm{~min}, 4^{\circ} \mathrm{C}\right.$ ) and the pellet was counted using a gamma counter. Nonspecific binding was performed for each sample using PBS.

\section{LIF bioassay}

The biological activity of the bovine anti-humanLIF antibody was assessed in a bioassay using 
murine myeloid leukaemic (M1) cells and performed by Dr DJ Hilton. In the absence of LIF, the M1 cells proliferate while in the presence of LIF, the cells differentiate into macrophages. M1 cells were cultured in agar with $500 \mathrm{U} / \mathrm{mL}$ of E coli derived non-glycosylated human LIF (tenfold higher than half maximal dilution). Doses of the antibody, $(0-50 \mu \mathrm{g} / \mathrm{mL})$ in two-fold dilutions were added to cultures. The assay was performed twice.

\section{Passive immunisation of ewes with LIF antibodies}

The oestrous cycles of 100 parous Corriedale ewes were synchronised as described (Salamonsen et al, 1986). Ewes were mated at the subsequent oestrus and divided into five groups: group $\mathrm{Cl}$ : untreated controls $(n=24)$; groups L1 and L2: treated with anti-LIF IgG ( $n=19 /$ group); and groups K1 and K2: treated with anti-KLH IgG ( $n=19 /$ group). Passive immunisation coincided with either blastocyst development to hatching (days 6-10; groups L1 and $\mathrm{K} 1$ ) or blastocyst elongation to implantation (days 12-16; groups L2 and K2).

\section{Passive immunisation}

Ewes received $30 \mathrm{~mL}(67 \mathrm{mg} / \mathrm{mL}$ of $\mathrm{IgG} ; 3 \mathrm{~min})$ administered into the jugular vein. Second and third injections of $15 \mathrm{~mL}$ were similarly administered at 2-day intervals.

\section{Blood sampling and testing of antiserum levels}

Blood samples were collected: $15 \mathrm{~min}$ after first injection, prior to the second, third injections and every alternate day up to day 35 . Undiluted serum was assayed.

\section{Confirmation of pregnancy}

Ewes were run with fertile rams bearing crayon mating markers and checked daily to determine which returned to service. Ultrasounds were performed at day 55 .

\section{Collection of tissue and uterine flushings}

Six animals from control ( $\mathrm{Cl}$ and $\mathrm{K} 1)$ groups that had returned to service were used for this second experiment. Three were passively immunised with anti-LIF (days 6-10), while three animals, were re-injected with anti-KLH (days 6-10). Animals were killed (day 12), their uteri flushed and the presence of a blastocyst was determined microscopically. Uterine flushings were concentrated 20-fold (Centricon-10 tubes Micron, MA, USA) and tested for anti-LIF by radioimmunoassay.

\section{Statistical analysis}

Logistic regression analysis was used to test which factors: 1) condition (immunised or nonimmunised), 2) treatment type (anti-LIF, anti$\mathrm{KLH}$ or untreated) or 3) schedule (immunised; days [6-10] or [12-16]) significantly $(P<0.05)$ reduced the pregnancy rate.

\section{Active immunisation of cows with LIF: effect on early pregnancy}

Immunisation and synchronisation of the oestrous cycle were performed, so that anti-LIF titres would be maximal around the time of implantation (fig 1). Cows actively immunised with LIF and KLH (experiment 1, 12 months earlier), were subjected to a booster injection of $50 \mu \mathrm{g}$ of LIF or KLH in Freund's incomplete adjuvant. Cows. had their oestrous cycles synchronised and were artificially inseminated at 12 and $24 \mathrm{~h}$ after oestrus. Blood was sampled (fig 1) and diluted serum $(1: 2000)$ binding to ${ }^{125}$ I-LIF was determined. Ultrasounds were performed on day 36.

\section{RESULTS}

\section{Active immunisation of cows with LIF}

Western blot analysis (fig 2) demonstrated that by third injection, all cows actively immunised with LIF had developed antibodies (bovine anti-human LIF antiserum), which recognised human LIF (approximately $20 \mathrm{kDa}$ ). Control animals showed 


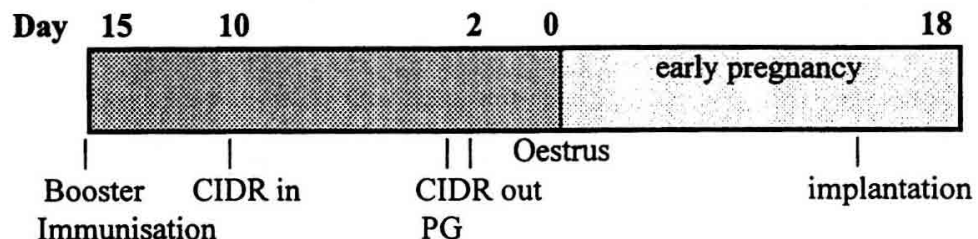

Immunisation

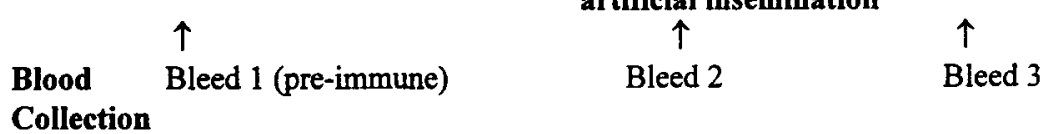

Bleed 4 (taken 41 days after oestrus) Bleed 5 (taken 75 days after oestrus)

Fig 1. Diagram showing the sequence of events involved in synchronisation of the bovine oestrous cycle, artificial insemination and active immunisation with LIF or KLH of cows prior to early pregnancy.

\section{kDA}

$20-$

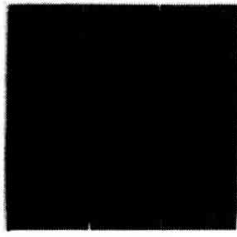

123
Fig 2. Western blot analysis. Lanes 1, 2 and 3 represent sera from cows 1,2 and 3 , respectively, which recognise human recombinant non-glycosylated LIF $(20 \mathrm{kDa})$.

Table I. Activity of bovine anti-human LIF antibody in LIF bioassay using M1 cells.

\begin{tabular}{cccccc}
\hline \multirow{2}{*}{$\begin{array}{c}\text { [Antibody] } \\
(\mu \mathrm{g} / \mathrm{mL})\end{array}$} & \multicolumn{2}{c}{ Experiment 1} & & \multicolumn{2}{c}{ Experiment 2 } \\
\cline { 2 - 3 } \cline { 5 - 6 } & $\begin{array}{c}\text { No colonies } \\
\text { undifferentiated }\end{array}$ & $\begin{array}{c}\text { No colonies } \\
\text { differentiated }\end{array}$ & & $\begin{array}{c}\text { No colonies } \\
\text { undifferentiated }\end{array}$ & $\begin{array}{c}\text { No colonies } \\
\text { differentiated }\end{array}$ \\
\hline 0 & 0 & 8 & & 0 & 13 \\
1.62 & 0 & 7 & & 0 & 11 \\
3.12 & 0 & 13 & & 0 & 23 \\
6.25 & 11 & 82 & & 0 & 34 \\
12.5 & 41 & 49 & & 58 & 54 \\
25 & 92 & 16 & & 106 & 51 \\
50 & 97 & 0 & 134 & 0 \\
\hline
\end{tabular}

Bioactivity of the antibody was assessed by its ability to inhibit the LIF induced differentiation of cultured M1 cells.

no binding. When this antibody was combined with LIF at $50 \mu \mathrm{g} / \mathrm{mL}$ (table I) it inhibited the ability of LIF to induce the differentiation of M1 colonies. The activity of the antibody was half maximal at about $12.5 \mu \mathrm{g} / \mathrm{mL}$. The antibody had no inhibitory effect below 6.25 and $12.5 \mu \mathrm{g} / \mathrm{mL}$, in experiment 1 and 2, respectively. 


\section{Passive immunisation of ewes with LIF antibodies}

During the passive immunisation, seven animals died (six immunised with anti-LIF and one with anti-KLH). Post-mortem examinations (University of Melbourne, School of Veterinary Science) indicated that the deaths may have been due to toxic shock. In view of the possibility that endotoxins may have been present in the IgG preparations, IgG awaiting injection on days $12-16$ was treated to remove endotoxin. However, four of the seven deaths occurred subsequently.

\section{${ }^{125}$ I-LIF binding to sera of passively immunised ewes}

All ewes receiving anti-LIF IgG had measurable serum titres of LIF antibody while all pre-immune sera and sera of animals injected with anti-KLH contained no detectable anti-LIF. Data for four ewes in groups $\mathrm{L} 1$ and $\mathrm{L} 2$ and one in each of groups $\mathrm{K} 1$ and $\mathrm{K} 2$ are represented in figure 3 . All animals injected with anti-LIF had measurable levels in serum until at least day 35 . Bleeds taken prior to the secondary and tertiary injection usually showed a slight increase in LIF antibody titre compared to those taken 15 min after the primary injection. Both groups of animals (fig 3a, b) showed the highest anti-LIF titres 6 days after the tertiary injection, on day 16 (fig 3a) and day 22 (fig $3 b$ ), respectively. By day 22 (fig 3a) and day 35 (fig 3b) anti-LIF titres began to decrease.

\section{${ }^{125}$ I-LIF binding in uterine luminal flushings of passively immunised ewes}

${ }^{125}$ I-LIF binding was demonstrated in uterine luminal flushings of ewes injected with antiserum in the second phase of experiment 2 and killed on day 12 of pregnancy (fig 4). Flushings from animals immunised
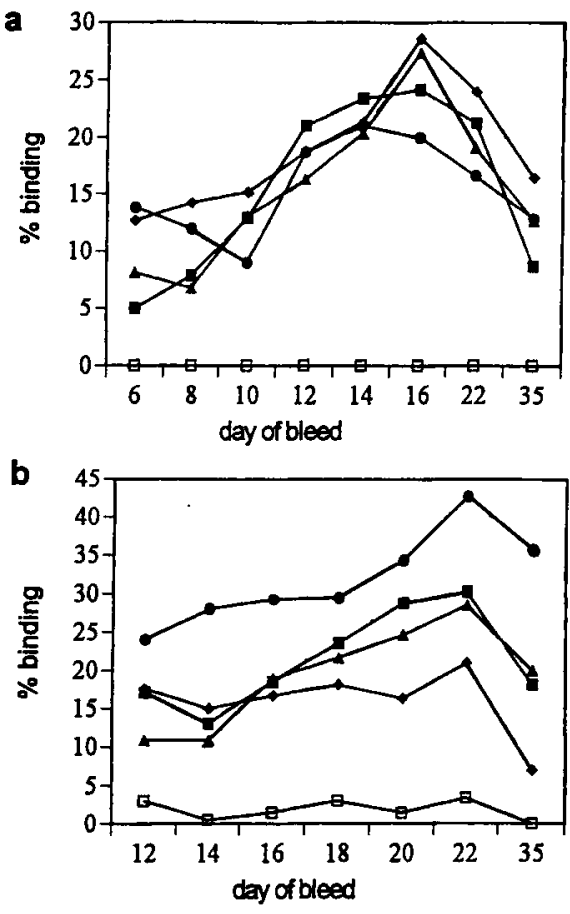

Fig 3. Binding of ${ }^{125} \mathrm{I}-\mathrm{LIF}$ to serial serum samples from individual ewes, between the day of the first injection of anti-LIF and day 35 of pregnancy. Data is expressed as \% specific binding, (a) animals injected on days 6,8 and 10 of pregnancy, (b) animals injected on days 12,14 and 16 of pregnancy. Shaded boxes $=$ four representative animals injected with anti-LIF, and open boxes = one representative animal injected with anti-KLH.

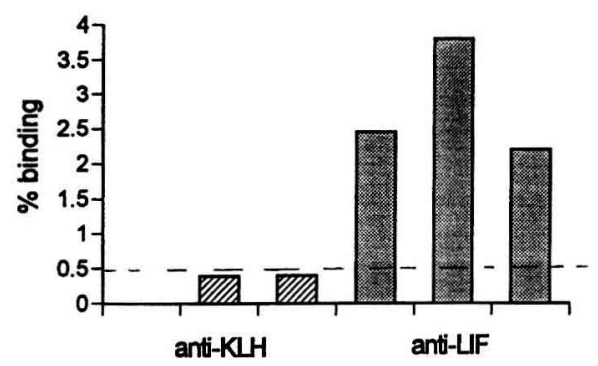

Fig 4. Binding of ${ }^{125} \mathrm{I}$-LIF to anti-LIF in uterine flushings of individual animals receiving antiLIF and anti-KLH on day 12 of pregnancy. Specific binding of antibody is shown above the dotted line. 
Table II. Pregnancy rates following passive immunisation of pregnant ewes against LIF and KLH.

\begin{tabular}{lcccc}
\hline Group & Total/group & Total pregnant & Total non-pregnant & Pregnancy rate \\
\hline C1 Control & 24 & 15 & 9 & $62.5 \%$ \\
L1 Anti-LIF & 16 & 7 & 9 & $40.6 \%$ \\
L2 Anti-LIF & 16 & 6 & 10 & \\
K1 Anti-KLH & 18 & 11 & 7 & $59.5 \%$ \\
K2 Anti-KLH & 19 & 11 & 8 & \\
\hline
\end{tabular}

$\mathrm{C} 1=$ untreated ewes; $\mathrm{L} 1=$ anti-LIF treated ewes on days 6-10; L2 = anti-LIF treated ewes on days 12-16; K1 = anti-KLH treated ewes on days $6-10 ; \mathrm{K} 2=$ anti $\mathrm{KLH}$ treated ewes on days $12-16$.

with anti-LIF showed approximately $3 \%$ specific binding to iodinated LIF compared with a mean binding of $0.27 \%$ to flushings from three animals injected with anti-KLH.

\section{Comparison of pregnancy rates in passively immunised ewes}

Pregnancy rates in the groups of ewes are given (table II). There were no significant differences between groups L1, L2 or K1, $\mathrm{K} 2$, data were pooled for final analysis. Anti-LIF animals showed a $33.5 \%$ decrease in pregnancy rate, compared with control and anti-KLH groups, but this was not statistically significant $(P>0.05)$.

\section{Active immunisation of cows with LIF: effect on early pregnancy}

The effect of active immunisation against LIF was assessed during early pregnancy in the cow. Binding to ${ }^{125}$ I-LIF was detected in serum of animals actively immunised with LIF (fig 5) and antibody levels were elevated in all three cows at the

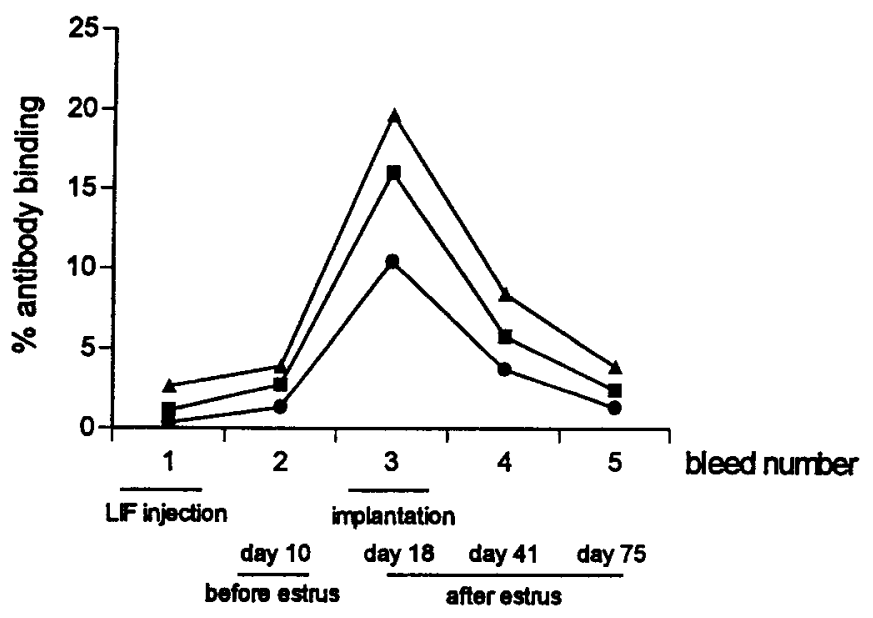

Fig. 5 Percentage binding of ${ }^{125}$ I-LIF to cow sera following booster injections to actively immunised cows prior to artificial insemination. The bleed numbers correspond to those shown in figure 1 and in the text, all sera were diluted 1:2000. $\square$ cow 1, cow 2, cow 3 . 
expected time of implantation. No binding was detected in serum of the cows immunised with KLH. Two of the animals actively immunised with LIF were not pregnant, whereas all three control animals were pregnant.

\section{DISCUSSION}

A decrease in pregnancy rate in ewes that were passively immunised against LIF was observed in comparison to animals in control groups, although this was not statistically significant. Furthermore, cows actively immunised with recombinant human LIF and exhibiting high levels of LIF antibodies in their serum at the time of blastocyst implantation also showed a reduced pregnancy rate in comparison to control animals.

Purified bovine IgG, which was shown to be biologically active owing to its ability to inhibit LIF induced differentiation of cultured M1 cells, was injected into each ewe. Anti-LIF was detected in serum as early as 15 min after the primary injection into the jugular vein, but the highest antibody titres occurred 6 days after the final injection. This could indicate that anti-LIF may be sequestered within tissues, possibly by binding to its ligand, and slowly released back into the circulation. When LIF binds in vitro to cells containing high affinity receptors (bone marrow, resident peritoneal cells, hepatocytes and M1 cells) less than 50\% dissociation occurs after $20 \mathrm{~h}$ at $4{ }^{\circ} \mathrm{C}$, while dissociation of LIF from transgenic peritoneal cells is biphasic with a rapid $\left(\mathrm{t}^{1 / 2}=2 \mathrm{~min}\right)$ and a slow component $\left(\mathrm{t}^{1 / 2}>20 \mathrm{~h}\right)$ corresponding to the numbers of low and high affinity receptors, respectively (Hilton et al, 1992). In this study the highest concentration of anti-LIF binding to ${ }^{125}$ ILIF in serum occurred at least 4 days after the final immunisation, while studies in vitro have indicated that the half-life of LIF bound to high affinity LIF receptors in certain cells is about 1 day at $4{ }^{\circ} \mathrm{C}$. Locally produced
LIF and injected anti-LIF may be complexed in tissues where there are high local concentrations of the LIF ligand, and as antiLIF is released from these complexes, it may re-enter the circulation and become accessible to bind to ${ }^{125}$ I-LIF in the assay.

The important question in passive immunisation studies is whether or not the antiserum binds the antigen to a sufficient extent to prevent its action. In the present study where production and actions of LIF are within the embryo-endometrial axis, it was important to show that the antiserum reaches the uterine lumen. In this study, anti-LIF was detected in the uterine flushings of animals treated with anti-LIF, but not in control animals. The similar rates of pregnancy between the two groups injected with LIF antibodies suggest that in the sheep LIF may be involved in both blastocyst development and implantation, but may not be obligatory for either process. Animals passively immunised with KLH antibodies showed the same pregnancy rate as untreated ewes, indicating that the immunisation regimen itself, was not the cause of the decrease in pregnancy. Previous studies have also demonstrated that specific antibodies can be detected in the uterus following passive immunisation. Parr and Parr (1986) demonstrated that IgG in mouse serum is taken up by uterine luminal and glandular epithelial cells (Wang et al, 1989). Furthermore, serum proteins selectively enter the uterine lumen. Sheep uterine flushings contain a large number of serum proteins, which include IgG (Salamonsen et al, 1984).

During the passive immunisation six ewes all immunised with anti-LIF and one immunised with anti-KLH died within $24 \mathrm{~h}$ of antibody administration. Both sets of IgG preparations were raised and purified under identical conditions. Therefore the greater mortality in the anti-LIF treated groups suggests a direct toxic effect of antiLIF by binding to locally produced LIF; a diverse range of cells bind and/or are 
affected by LIF (Hilton, 1992; Metcalf, 1992).

When cows that had been actively immunised with LIF or KLH had their antibody levels boosted during the early stages of pregnancy, the pregnancy rate of the LIF immunised animals was reduced with only one in three cows pregnant in comparison to all cows $(n=3)$ pregnant in the control groups. These preliminary findings indicate that LIF may play a role in early pregnancy in the cow. Active immunisation studies with larger numbers of animals were not possible owing to the quantity of antigen required and the cost of the animals.

Passive immunisation against LIF during early pregnancy did not prevent $60 \%$ of ewes from establishing that pregnancy. One possible explanation is that the actions of uterine LIF were not completely blocked in some animals, thus allowing embryonic development and implantation to take place. Alternatively, as the extent of implantation varies between species (Wooding and Flint, 1994), physiological differences could explain why LIF is not obligatory for implantation in ruminants. Furthermore, other cytokines such as ciliary neurotrophic factor (CNTF) and oncostatin M (OSM), which are related to LIF and utilise the signalling system involving the LIF receptor complex (LIFR and gp130), may function when LIF is absent or reduced in the uterus during early pregnancy (Ip et al, 1992; Taga and Kishimoto, 1992; Gearing et al, 1992; Davis et al, 1993). To date, these cytokines have been demonstrated in the human, however sheep and cow tissue have not been examined. Overall, these results suggest that while LIF may have a role in embryo development, implantation and pregnancy in ruminants, it is not critical as it appears in the mouse. Further, they highlight the possibility that LIF may have different or lesser roles in these processes in different species.

\section{ACKNOWLEDGMENTS}

The authors are grateful to Dr R Parr and P Trimbos for assistance during animal handling procedures, Dr DJ Hilton (Walter and Elisa Hall Institute of Medical Research) for the generous provision of iodinated LIF and for performing the LIF bioassay, Professor J Findlay for the critical reading of the manuscript. The AMRAD Corporation and AMRAD Pharmacia Biotech, provided the recombinant LIF and antibody respectively. DV was supported by the Victorian Education Foundation and LAS by the $\mathrm{NH}$ \& MRC of Australia.

\section{REFERENCES}

Arici A, Engin O, Attar E, Olive DL (1995) Modulation of leukemia inhibitory factor gene expression and protein biosynthesis in human endometrium. $J$ Clin Endocrinol Metab 80, 1908-1914

Bhatt H, Brunet LJ, Stewart CL (1991) Uterine expression of leukemia inhibitory factor coincides with the onset of blastocyst implantation. Proc Natl Acad Sci 88, 11408-11412

Bindon BM (1971) Systematic study of preimplantation stages of pregnancy in the sheep. Aus J Biol SCi 24, 131-147

Charnock-Jones DS, Sharkey AM, Fenwick P, Smith SK (1994) Leukemia inhibitory factor mRNA concentration peaks in human endometrium at the time of implantation and the blastocyst contains mRNA for the receptor at this time. I Reprod Fertil 101 , $421-426$

Cullinan EB, Abbndanzo SJ, Anderson PS, Pollard JW, Lessey BA, Stewart CL (1996) Leukemia inhibitory factor (LIF) and LIF receptor expression in human endometrium suggests a potential autocrine/paracrine function in regulating embryo implantation. Proc Natl Acad Sci USA 93, 31153120

Davis S, Aldrich TH, Stahl N, Pan L, Taga T, Kishomoto T, Ip NY, Yancopoulos GD (1993) LIFR $\beta$ and gp 130 as heterodimerising signal transducers of the tripartite CNTF receptor. Science 260, 1805-1808

Fang WD, Mukkur TKS (1976) Physiochemical characterisation of proteolytic cleavage fragments of bovine colostral immunoglobulin $\mathrm{G}^{1}\left(\mathrm{IgG}^{1}\right)$. Biochem J 155, 25- 30

Finn CA, McLaren A (1967) A study of the early stages of implantation. J Reprod Fertil 13, 259-267

Fry RC, Batt PA, Fairclough RJ, Parr RA (1992) Human leukemia inhibitory factor improves the viability of cultured ovine embryos. Biol Reprod $46,470-474$ 
Gearing DP, Comeau MR, Friend DJ, Gimpel SD, Thut CJ, McGourty J, Brasher KK, King JA, Gillis S, Mosley J, Zieger SF, Cosman D (1992) The IL-6 signal transducer, gp 130: An oncostatin receptor and affinity converter for the LIF receptor. Science $255,1434-1437$

Hilton DJ (1992) LIF: lots of interesting functions. Trends Biochem Sci 17, 72-76

Hilton DJ, Nicola NA (1992) Kinetic analyses of the binding of leukemia inhibitory factor to receptor on cells and membranes and in detergent solution. J Biol Chem 267, 10238-10247

Hilton D J, Nicola NA,. Metcalf D (1992) Distribution and binding properties of receptors for leukaemia inhibitory factor. In: Polyfunctional Cytokines: $I L-6$ and LIF. Ciba Foundation Symposium (GR Bock, K Widdows, eds), John Wiley \& Sons Ltd, West Sussex, 227-244

Ip NY, Nye SH, Boulton TG, Davis S, Taga T, Li Y, Birren SJ, Yasukawa K, Kishimoto T, Anderson DJ Stahl N, Yancopoulos GD (1992) CNTF and LIF act on neuronal cells via shared signaling pathways that involve the IL-6 signal transducing receptor compnent gp130. Cell 69, 1121-1132

Kojima K, Kanzaki H, Iwai M, Hatayama H, Fujimoto M, Ioue T, Horie K, Nakayama H, Fujita J, Mori T (1994) Expression of leukemia inhibitory factor in human endometrium and placenta. Biol Reprod 50 , 882-887

Lavranos TC, Rathjen PD, Seamark RF (1995) Trophic effects of myeloid leukaemia inhibitory factor (LIF) on mouse embryos. I Reprod Fertil 105, 331-338

Metcalf D (1992) Leukemia inhibitory factor a puzzling polyfunctional regulator. Growth Factors 7 , 169-173

Orsini M W, McLaren A (1967) Loss of the zona pellucida in mice, and the effect of tubal ligation and ovariectomy. I Reprod Fertil 13, 485-499

Parr EL, Parr MB (1986) Uptake of immunoglobulins and other proteins from serum into epithelial cells of the mouse uterus and oviduct. $J$ Reprod Immunol 9, 339-354

Robertson SA, Lavranos TC, Seamark RF (1991) In vitro models of the maternal-fetal interface. In: Molecular and Cellular Immunobiology of the Maternal Fetal Interface (TG Wegmann, TG Gill III, E Nisbet-Brown, eds), University Press, New York, 191-206

Rowson LEA, Moor RM (1976) The corpus luteum of the sheep: effect of the removal of embryos on luteal function. $J$ Endocrinol 34, 497-502
Salamonsen LA, Doughton B, Findlay, JK (1984) Protein synthesis by preimplantation sheep blastocysts. In: Reproduction in Sheep (DA Lindsay, DT Pearce, eds), Australian Acedemy of Sciences, Canberra, 115-117

Salamonsen LA, Doughton BS, Findlay JK (1986) The effects of preimplantation blastocyst in vivo and in vitro on protein synthesis and secretion by cultured epithalial cells from sheep endometrium. Endocrinology 119, 622-628

Stewart CL, Kaspar P, Brunet LJ, Bhatt H, Gadi I, Kontgen F, Abbondanzo, ST (1992) Blastocyst implantation depends on maternal expression of leukaemia inhibitory factor. Nature 359, 76-79

Taga T, Kishimoto T (1992) Cytokine receptors and signal transduction. FASEB J 6, 3387-3396

Vogiagis D, Marsh M M, Fry RC, Salamonsen LA (1996a) Leukaemia inhibitory factor in human endometrium throughout the menstrual cycle. $J$ Endocrinol 148, 95-102

Vogiagis D, Fry RC, Sandeman RM, Squires T J, Salamonsen LA (1996b) Leukemia inhibitory factor in ovine blastocyst implantation: Its endometrial expression and the effect of passive immunization. $J$ Reprod Fert (in press).

Wang MW, Whyte A., King I, Taussig MJ, Heap RB (1989) Immunoflurescent localisation by use of anti-idiotypic antibody, of monoclonal anti-progesterone antibody in the mouse uterus before implantation. J Reprod Fertil 86, 211-218

Ware CB, Horowitz MC, Renshaw BR, Hunt JS, Liggitt D, Koblar SA, Gliniak BC, McKenna HJ, Papaynnopoulou T, Thoma B, Cheng L, Donovan PJ, Peschon JJ, Bartlett PF, Willis CR, Wright BD, Carpenter MK, Davidson BL, Gearing DP (1995) Targeted disruption of the low-affinity leukemia inhibitory factor receptor gene causes placental, skeletal, neural and metabolic defects and results in perinatal death. Development 121, 1283-1299

Wooding, FBP, Flint, APF (1994) Placentation. In: Marshall's Physiology of Reproduction, 4th ed. Pregnancy \& Lactation part 1, Ovulation and Early Pregnancy (GE Lamming, ed), Chapman \& Hall, London, 235-429

Yoshida K, Taga T, Saito M, Suematsu S, Kumanogoh A, Tanaka T, Fujiwara H, Hirata M, Yamagami T, Nakahata T, Hirabayashi T, Yoneda Y, Tanaka K, Wang W-Z, Mori C, Shiota K, Yoshida N, Kishimoto T. (1996) Targeted disrtuption of gp130, a common signal transducer for the interleukin 6 family of cytokines, leads to myocardial and hematological disorders. Proc Natl Acad Sci 93, 407411 